\title{
Telaah Potensi Materi Ajar Biologi SMP Berbasis pada Potensi Lokal di Bantaran Sungai Winongo Kabupaten Bantul
}

\author{
Muhammad Joko Susilo \\ Progam Studi Pendidikan Biologi, Universitas Ahmad Dahlan \\ Kampus III, Jl. Prof. Dr. Soepomo, SH, Yogyakarta, 55164 Indonesia \\ surat elektronik: jokoms_uad@,yahoo.com
}

\begin{abstract}
ABSTRAK
Kebutuhan akan materi pembelajaran yang berbasis pada potensi lokal belum banyak ditemukan dalam referensi/buku pegangan guru. Materi ajar yang kontekstual sangat diharapkan dalam pengembangan standar isi pada Kurikulum 2013. Penelitian ini bertujuan untuk: (I) mengetahui potensimateri ajar biologi yang ditemukan di bantaran sungai winongo Kabupaten Bantul, (2) mengetahui kesesuaian temuan-temuan materi berbasis potensi lokal dengan kebutuhan materi ajar biologi SMP yang memenuhi prinsip-prinsip relevansi, adequacy, dan konsistensi, dan (3) mengetahui kualitas prototipe/desain suplemen materi ajar yang dikembangkan dengan isi/bahan materi ajar berbasis potensi lokal untuk 3 Kompetensi Dasar versi Kurikulum 2013 di jenjang SMP.

Penelitian ini didesain dengan fragmen/penggalan dari penelitian pengembangan dengan langkah analisis kebutuhan dilakukan melalui penelitian eksplorasi di bantaran Sungai Winongo Kabupaten Bantul, selanjutnya dilakukan penelaahan mendalam tentang materi ajar yang ditemukan dari penelitian eksplorasi, dan dilanjutnya dengan mengembangkan prototipe suplemen materi ajar biologi SMP. Pengumpulan data dilakukan dengan observasi dan dokumentasi. Teknik analisis data dilakukan secara diskriptif kualitatif.

Hasil penelitian menunjukkan potensi materi ajar yang ditemukan di bantaran Sungai Winongo cocok untuk materi pencermaran tanah dan air. Selanjutnya, hasil analisis mendalam ditemukan materi ajar yang ditemukan sudah memenuhi kriteria materi ajar yang mencakup pengetahuan, sikap, dan ketrampilan juga memenuhi prinsip pengembangan materi yaitu relevansi, adequacy, dan konsistensi. Hasil pengujian kualitas suplemen materi ajar menunjukkan bahwa buku suplemen materi ajar dinyatakan layak dengan kategori baik
\end{abstract}

Kata kunci: pengembangan, suplemen materi ajar IPA (Biologi), potensi lokal

\section{Pendahuluan}

Adanya kebijakan penggantian kurikulum secara tidak langsung mengajak para guru khususnya yang mengampu mata pelajaran IPA (biologi) untuk mempersiapkan materi yang akan diajarkan denganbaik. Materi pembelajaran yang dipersiapkan harus sesuai dengan arah kebijakan yang tertuang dalam kurikulum dan sesuai dengan tuntutan serta kebutuhan masyarakat. Oleh karena itu, untuk mengembangkan kurikulum yang akan diterapkan seorang guru harus mengacu pada Undang-Undang No. 20 Tahun 2003 yang menyebutkan bahwa pengembangan kurikulum dilakukan dengan mengacu pada Standar Nasional Pendidikan dan kurikulum pada semua jenjang dan jenis pendidikan dikembangkan dengan prinsip diverifikasi sesuai dengan satuan pendidikan, potensi daerah, dan peserta didik.
Peraturan Pemerintah No. 19 Tahun 2005 menyebutkan bahwa standar yang terkait langsung dengan kurikulum adalah Standar Isi dan Standar Kompetensi Lulusan, dan telah diatur dalam Peraturan Menteri Pendidikan Nasional No. 22 Tahun 2006 tentang Standar Isi (SI) dan Peraturan Menteri Pendidikan Nasional No. 23 Tahun 2006 tentang Standar Kompetensi Lulusan (SKL) serta Peraturan Menteri Pendidikan Nasional No. 24 Tahun 2006 tentang Pelaksanaan SI dan SKL. Berdasarkan SI dan SKL, serta panduan yang disusun oleh BSNP, maka Satuan Pendidikan diharapkan dapat mengembangkan kurikulum sesuai dengan satuan pendidikan, potensi daerah/karakteristik daerah, social budaya masyarakat setempat, dan peserta didik.

Mengacu pada hasil penelitian Suratsih (2010) tentang pelaksanaan pembelajaran IPA KTSP SMP di Kabupaten Sleman Yogyakarta, menunjukan bahwa, 
(a) potensi lokal yang dimiliki sekolah belum dimanfaatkan secara optimal dalam kegiatan pembelajaran biologi, sedang pemanfaatan potensi sekolah merupakan salah satu karakteristik dalam pengembangan kurikulum, dan guru-guru biologi belum banyak berkarya untuk mengembangkan materi biologi yang berbasis potensi lokal/karakteristik yang ada di daerah setempat. Guru masih banyak menggunakan sumber belajar yang sudah tersedia di pasaran yang tidak cocok dengan kondisi sekolah maupun karakteristik siswa, sehingga masih harus dilakukan penyesuaianpenyesuaian. Berdasarkan argument tersebut, maka guru untuk berinovasi dan berkarya dengan mengkaji dan menyiapkan subject matter seoptimal mungkin yang berbasis pada potensi lokal/kedaerahan. Untuk itulah, usulan penelitian diajukan dalam satu paket penelitian pengembangan yang dipetakan dalam beberapa tahap pengembangan. Namun, karena ada keterbatasan maka dalam penelitian hanya diambilkan fragmen/penggalan alur riset pengembangan yaitu: ekplorasi dan analisis potensimateri IPA (biologi) berbasis potensi alam di Kabupaten Bantul sampai pada desain buku suplemen materi ajar yang berisi materi biologi SMP dengan mengangkat persoalan apa saja temuan-temuan materi berbasis potensi lokal tersebut sesuai dengan kebutuhan materi ajar biologi SMP dan memenuhi prinsip-prinsip relevansi, adequacy, dan konsistensi untuk membelajarkan biologi di jenjang SMP? ; Bagaimanakah kualitas buku suplemen materi ajar yang dikembangkan berbasis potensi lokal di jenjang SMP ?

\section{Metode Penelitian}

Penelitian ini didesain dengan fragmen/penggalan dari penelitian pengembangan dengan langkah analisis kebutuhan dilakukan melalui penelitian eksplorasi di sungai gajah wong Kabupaten Bantul. Subjek penelitian ini adalah guru biologi SMP. Pengambilan subjek guru dilakukan dengan teknik purposive random sampling. Langkah-langkah untuk mendapatkan data dalam rangka penyusunan buku suplemen materi ajar sebagai berikut: Melakukan penelitian eksplorasi potensi alam yang ada dibantaran Sungai Winongo Kabupaten Bantul, DIY sebagai sumber belajar IPA (biologi) untuk bahan penyusunan materi ajar biologi berbasis potensi lokal; Melakukan penelahaan hasil kajian penelitian eksplorasi untuk diidentifikasi potensi sebagai materi ajar biologi di jenjang SMP yang sesuai dengan Kurikulum 2013; Mendesain prototipe suplemen materi ajar sebagai wadah dari materi yang ditemukan dari hasil penelitian eksplorasi; Mengujikan desain buku suplemen materi ajar untuk mendapatkan kualitas dari isi materi ajar yang ditemukan; dan Menganalisis hasil pengujian desain buku suplemen materi ajar melalui uji terbatas oleh guru IPA (Biologi SMP). Pengumpulan data dilakukan dengan observasi dan dokumentasi. Teknik analisis data dilakukan secara diskriptif kualitatif.

\section{Hasil dan Pembahasan}

\section{A. Hasil Temuan Materi Ajar Biologi}

Tabel I. Kesesuaian temuan materi ajar berdasarkan hasil penelitian pencemaran air dan tanah di Sungai Winongo

\begin{tabular}{|c|c|c|c|c|}
\hline $\mathrm{K} / \mathrm{SK}$ & $\begin{array}{l}\text { Materi Ajar Tuntutan } \\
\text { Kurikulum } 2013\end{array}$ & $\mathrm{~K} / \mathrm{SK}$ & $\begin{array}{l}\text { Materi Ajar Hasil Penelitian di Sungai } \\
\text { Winongo }\end{array}$ & Keterangan \\
\hline $\mathrm{K}$ & Konsep Lingkungan & $\mathrm{K}$ & Konsep Lingkungan & \\
\hline SK-I & Komponen biotik & SK-I & & \\
\hline SK-2 & Komponen abiotik & SK-2 & & \\
\hline $\mathrm{K} / \mathrm{SK}$ & $\begin{array}{c}\text { Materi Ajar Tuntutan } \\
\text { Kurikulum } 2013\end{array}$ & $\mathrm{~K} / \mathrm{SK}$ & $\begin{array}{l}\text { Materi Ajar Hasil Penelitian di Sungai } \\
\text { Winongo }\end{array}$ & Keterangan \\
\hline K & $\begin{array}{l}\text { Interaksi ekosistem } \\
\text { membentuk pola }\end{array}$ & K & Interaksi ekosistem membentuk pola & \\
\hline SK-I & Rantai makanan & SK-I & & \\
\hline SK-2 & Jaring-jaring makanan & SK-2 & & \\
\hline SK-3 & Simbiosis & SK-3 & & \\
\hline $\mathrm{K} / \mathrm{SK}$ & $\begin{array}{c}\text { Materi Ajar Tuntutan } \\
\text { Kurikulum } 2013 \\
\end{array}$ & $\mathrm{~K} / \mathrm{SK}$ & $\begin{array}{c}\text { Materi Ajar Hasil Penelitian di Sungai } \\
\text { Winongo }\end{array}$ & Keterangan \\
\hline K & $\begin{array}{l}\text { Pola interaksi manusia } \\
\text { mempengaruhi ekosistem }\end{array}$ & $\mathrm{K}$ & $\begin{array}{l}\text { Pola interaksi manusia mempengaruhi } \\
\text { ekosistem }\end{array}$ & \\
\hline SK-I & $\begin{array}{l}\text { Pengertian pencemaran } \\
\text { lingkungan }\end{array}$ & SK-I & Pengertian Pencemaran lingkungan & $\begin{array}{l}\text { Terpenuhi. Ada pada LHP hal 26. Pencemaran } \\
\text { lingkungan merupakan masuknya atau } \\
\text { dimasukkannya makhluk hidup, zat, energi, dan } \\
\text { komponen lain ke dalam lingkungan oleh } \\
\text { kegiatan manusia atau oleh proses alam, sehingga } \\
\text { kualitas lingkungan turun sampai ke tingkat } \\
\text { tertentu yang menyebabkan lingkungan menjadi } \\
\text { kurang atau tidak berfungsi lagi sesuai dengan } \\
\text { peruntukkannya. }\end{array}$ \\
\hline SK-2 & $\begin{array}{l}\text { Syarat suatu zat disebut } \\
\text { polutan }\end{array}$ & SK-2 & Syarat suatu zat disebut polutan & $\begin{array}{l}\text { Terpenuhi. Ada pada LHP hal 27.Syaratnya: } \\
\text { jumlah melebihi jumlah normal; berada pada } \\
\text { waktu yang tidak tepat; dan berada pada tempat } \\
\text { yang tidak tepat. }\end{array}$ \\
\hline
\end{tabular}




\begin{tabular}{|c|c|c|c|c|}
\hline $\mathrm{K} / \mathrm{SK}$ & $\begin{array}{c}\text { Materi Ajar Tuntutan } \\
\text { Kurikulum } 2013 \\
\end{array}$ & $\mathrm{~K} / \mathrm{SK}$ & $\begin{array}{c}\text { Materi Ajar Hasil Penelitian di Sungai } \\
\text { Winongo }\end{array}$ & Keterangan \\
\hline $\mathrm{K}$ & $\begin{array}{l}\text { Macam pencemaran } \\
\text { lingkungan }\end{array}$ & $\mathrm{K}$ & Macam pencemaran lingkungan & \\
\hline SK-I & $\begin{array}{l}\text { Pencemaran udara beserta } \\
\text { akibat yang ditimbulkan. }\end{array}$ & SK-I & & \\
\hline SK-2 & $\begin{array}{l}\text { Pencemaran suara beserta } \\
\text { akibat yang ditimbulkan }\end{array}$ & SK-2 & & \\
\hline SK-3 & $\begin{array}{l}\text { Pencemaran air, penyebab, } \\
\text { sumber pencemaran, } \\
\text { beserta akibat yang } \\
\text { ditimbulkan }\end{array}$ & SK-3 & $\begin{array}{l}\text { Pencemaran air, penyebab, sumber } \\
\text { pencemaran, beserta akibat yang } \\
\text { ditimbulkan }\end{array}$ & $\begin{array}{l}\text { Terpenuhi. Dengan data tentang penyebab } \\
\text { pencemaran air darirembesan sampah anorganik } \\
\text { yang ada dibantaran sungai, sumber pencemaran } \\
\text { dari limbah rumah tangga, akibat yang } \\
\text { ditimbulkan air tidak layak untuk diminum, } \\
\text { organisme yang hidup di air akan mati, produksi } \\
\text { tanaman menurun, peralatan akan rusak karena } \\
\text { air bersifat korosif. }\end{array}$ \\
\hline SK-4 & $\begin{array}{l}\text { Pencemaran tanah, } \\
\text { penyebab, sumber } \\
\text { pencemaran, beserta } \\
\text { akibat yang ditimbulkan }\end{array}$ & SK-4 & $\begin{array}{l}\text { Pencemaran tanah, penyebab, sumber } \\
\text { pencemaran, beserta akibat yang } \\
\text { ditimbulkan }\end{array}$ & $\begin{array}{l}\text { Terpenuhi. Dengan data berupa sampah } \\
\text { anorganik yang banyak ditemukan di bantaran } \\
\text { Sungai Winongo, meliputi: plastik, kertas, kain, } \\
\text { asbes, sterofom, karet, kaca, logam, bahan kimia, } \\
\text { dan busa; sumber pencemaran dari limbah rumah } \\
\text { tangga; akibat yang ditimbulkan pengikisan } \\
\text { sungai sehingga sungai tambah lebar mendekati } \\
\text { rumah warga, banjir } 2 \text { kali dalam setahun, serta } \\
\text { timbul bau menyengat. }\end{array}$ \\
\hline $\mathrm{K} / \mathrm{SK}$ & $\begin{array}{c}\text { Materi Ajar Tuntutan } \\
\text { Kurikulum } 2013\end{array}$ & K / SK & $\begin{array}{c}\text { Materi Ajar Hasil Penelitian di Sungai } \\
\text { Winongo }\end{array}$ & Keterangan \\
\hline $\mathrm{K}$ & Pengurangan limbah & K & Pengurangan limbah & $\begin{array}{l}\text { Terpenuhi. Dengan menerapkan } 3 \text { R (Reduce, } \\
\text { Reuse, dan Recycle), Disposal. }\end{array}$ \\
\hline $\mathrm{K} / \mathrm{SK}$ & $\begin{array}{l}\text { Materi Ajar Tuntutan } \\
\text { Kurikulum } 2013\end{array}$ & $\mathrm{~K} / \mathrm{SK}$ & $\begin{array}{l}\text { Materi Ajar Hasil Penelitian di Sungai } \\
\text { Winongo }\end{array}$ & Keterangan \\
\hline $\mathrm{K}$ & Pemanasan Global & $\mathrm{K}$ & & \\
\hline
\end{tabular}

\section{B. Hasil Analisis Mendalam Ketentuan Materi Ajar Yang Ditemukan}

Tabel 2. Keterpenuhan Kriteria dan Prinsip Materi Ajar Pencemaran Air Di Bantaran Sungai Winongo Kabupaten Bantul

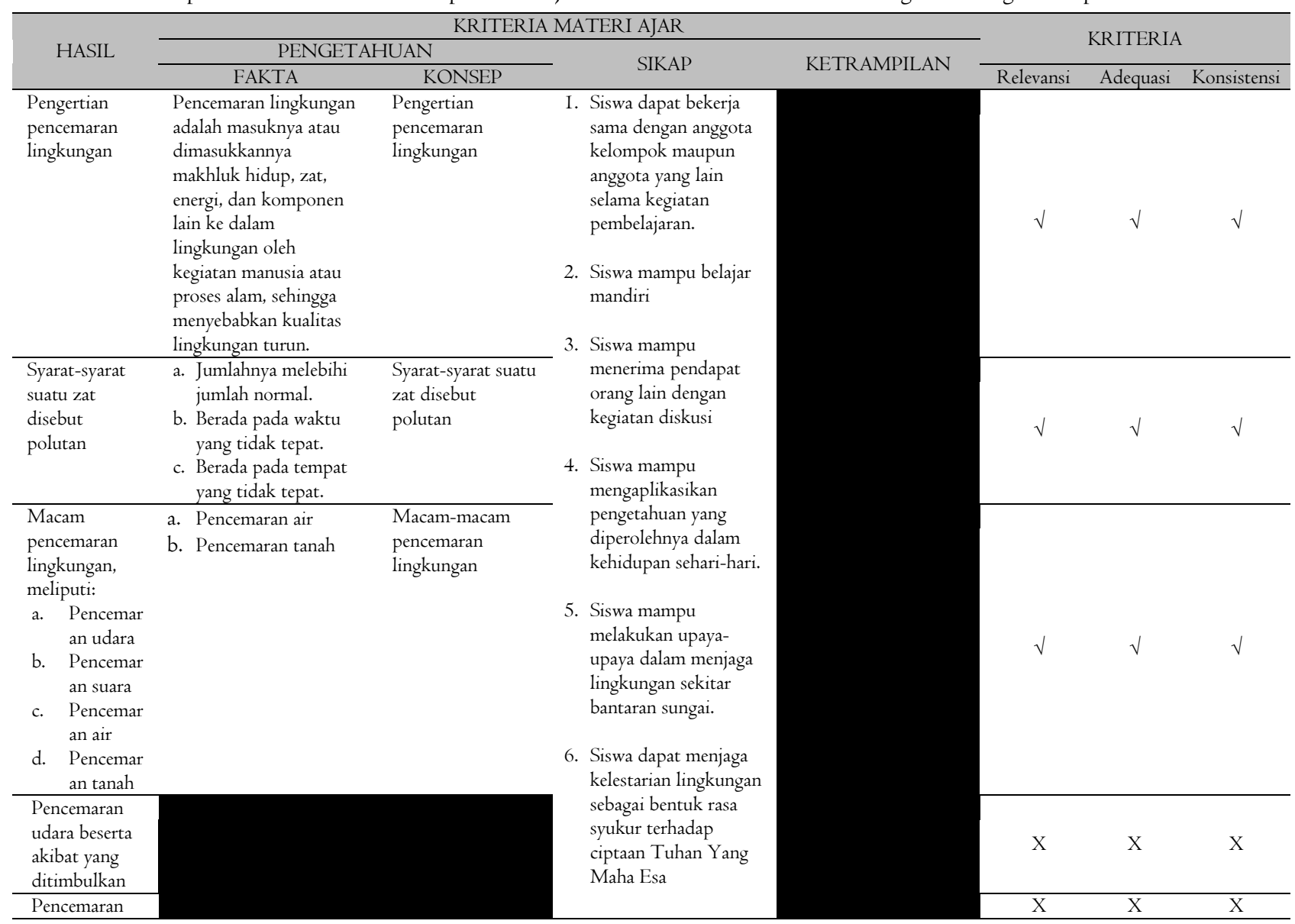




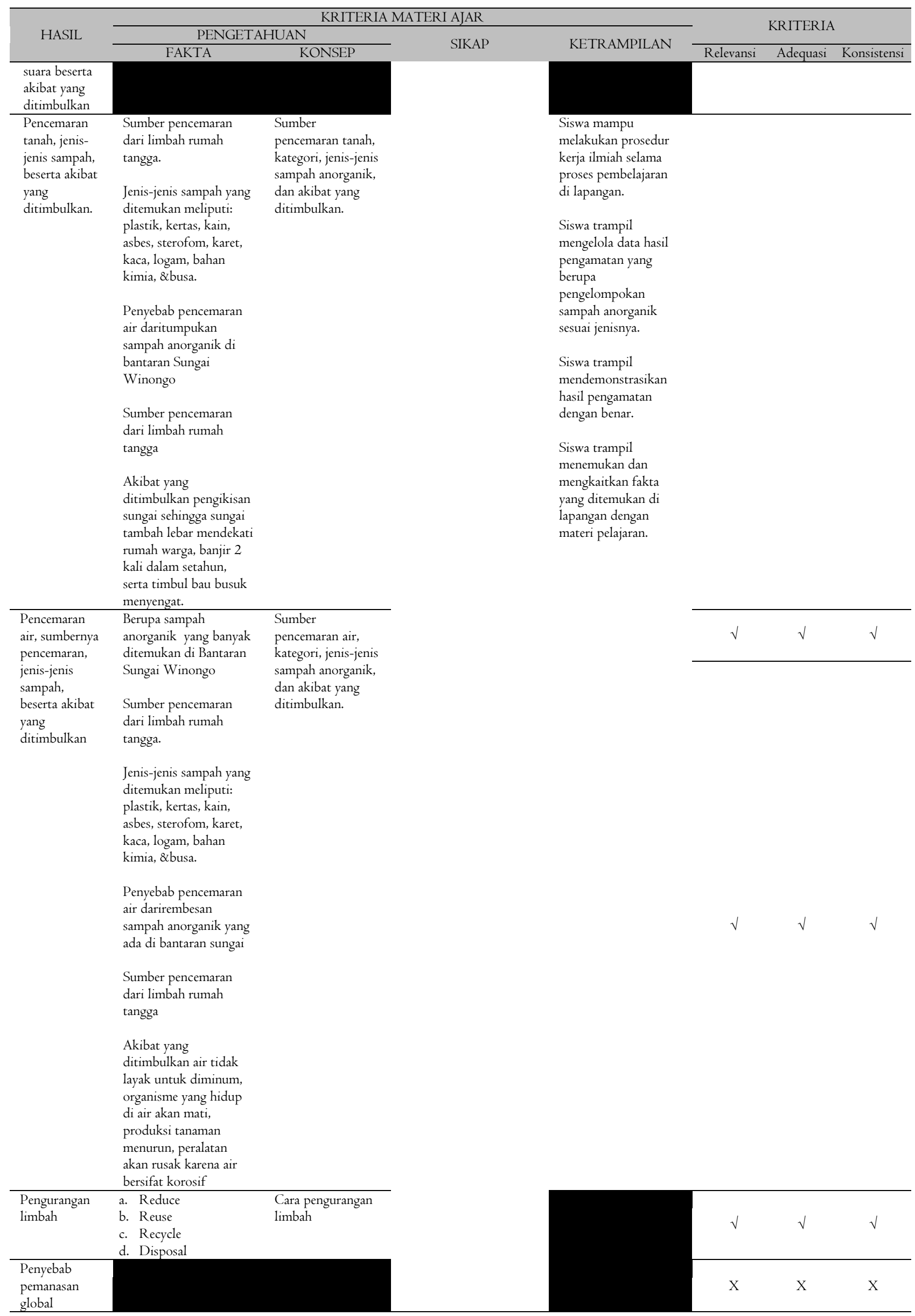




\section{Data Hasil Penilaian Produk}

Data hasil penilaian buku suplemen materi ajar oleh guru IPA (Biologi) SMP dapat disajikan pada Tabel 3 sebagai berikut.

Tabel 3. Kualitas Buku Suplemen Materi Ajar Pencemaran Air \& Tanah Berdasarkan Penilaian Guru IPA (Biologi) SMP

\begin{tabular}{|c|c|c|c|c|}
\hline No. & Aspek & & Persentase & Kategori \\
\hline \multirow{3}{*}{ I. } & \multirow{3}{*}{ Materi } & Relevansi & 90,5 & Baik \\
\hline & & Konsistensi & $\mathrm{IOO}$ & Baik \\
\hline & & Adequacy & 94,6 & Baik \\
\hline \multirow{2}{*}{2.} & \multirow{2}{*}{ Penyajian } & Tampilan & 100 & Baik \\
\hline & & Aturan Penulisan & 100 & Baik \\
\hline 3. & Keterbacaan & Kebahasaan & 83,3 & Baik \\
\hline \multicolumn{3}{|c|}{ Keseluruhan } & 94,7 & Baik \\
\hline
\end{tabular}

Berdasarkan Tabel 3. penilaian kualitas buku suplemen materi ajar yang dinilai oleh guru IPA (Biologi) SMP dapat disajikan dalam diagram berikut ini.

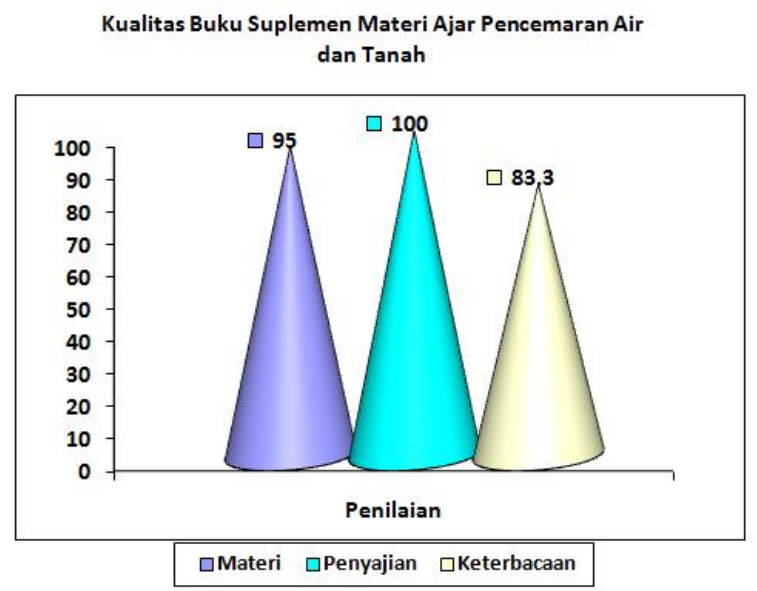

Gambar I. Diagram Penilaian Kualitas Buku Suplemen Materi Ajar Pencemaran Air \& Tanah Berdasarkan Penilaian Guru IPA (Biologi) SMP

Berdasarkan uji penilaian oleh guru IPA (Biologi) SMP diperoleh hasil bahwa secara keseluruhan buku suplemen materi ajar dalam kategori baik dengan presentase $94,7 \%$. Semua aspek yang rata-rata menunjukkan hasil jawaban "Ya". Hal tersebut menunjukkan bahwa buku suplemen materi ajar yang disusun memperoleh predikat layak digunakan untuk tambahan materi pembelajaran yang berbasis pada potensi lokal dari Bantaran Sungai Winongo Kabupaten Bantul dan tidak menutup kemungkinan bisa digunakan sebagai model bagi wilayah-wilayah lain pada materi ajar yang sejenis.

\section{Revisi Produk}

Revis produk dilakukan untuk menyempurnakan produk buku suplemen materi ajar yang telah dikembangkan. Revisi produk dilakukan setelah memperoleh penilaian dari uji ahli, yaitu guru IPA (Biologi) SMP. Berikut merupakan masukan dari catatan-catatan guru IPA (Biologi) SMP tentang suplemen materi ajar yang sudah disusun untuk direvisi.
Tabel 4. Hasil Revisi Buku Suplemen Materi Ajar Pencemaran Air dan Tanah Sebelum dan Sesudah Penilaian dari Guru IPA (Biologi SMP)

\begin{tabular}{ll}
\hline \multicolumn{1}{c}{ Sebelum Revisi } & \multicolumn{1}{c}{ Sesudah Revisi } \\
\hline Penulisan sesuai dengan EYD: & \\
\hline Hal I4 = tertulis 4 proses & $\begin{array}{l}\text { Hal I4 = tertulis 4 proses, } \\
\text { karena kesalahan editor }\end{array}$ \\
\hline $\begin{array}{l}\text { Hal I4 = pengurangan } \\
\text { limbah }\end{array}$ & $\begin{array}{l}\text { Hal I4 = pengelolaan } \\
\text { limbah }\end{array}$ \\
\hline $\begin{array}{l}\text { Hal } 4=\text { tidak dilengkapi } \\
\text { sumber }\end{array}$ & $\begin{array}{l}\text { Hal } 4=(\text { Sumber: } \\
\text { wawancara oleh Vitanovi } \\
\text { (20I4)). }\end{array}$ \\
\hline Hal 4 = ego & Hal 4 = keinginan \\
\hline $\begin{array}{l}\text { Peta konsep belum menunjukkan keterkaitan antarkonsep } \\
\text { sehingga perlu kata penghubunga (konektor): }\end{array}$ \\
$\begin{array}{ll}\text { Hal I = peta konsep tanpa } \\
\text { konektor }\end{array}$ & $\begin{array}{l}\text { Hal I }=\text { peta konsep ada } \\
\text { diatasi dengan) }\end{array}$ \\
\hline Gambar belum ada sumber: & \\
\hline $\begin{array}{l}\text { Hal 5-I6 = tidak ada } \\
\text { sumber gambar }\end{array}$ & $\begin{array}{l}\text { Hal 5-I6 = ada sumber } \\
\text { gambar } \\
\text { (Vitanovi, 20I4). }\end{array}$ \\
\hline
\end{tabular}

Revisi buku suplemen materi ajar dilakukan setelah mendapat penilaian dari guru IPA (Biologi) SMP. Berdasarkan saran dan masukan dari penilai (guru), peneliti perlu melakukan revisi terhadap produk buku suplemen materi ajar. Saran yang diberikan mengenai penulisan istilah/kata yang belum sesuai dengan EYD, alur peta konsep dan sumber gambar. Sebagai tindak lanjut, maka sebagian besar saran yang diberikan diterima untuk perbaikan penyusunan buku suplemen materi ajar.

Penelitian pengembangan buku suplemen materi ajar biologi SMP berdasarkan hasil penelitianeksplorasi potensi lokal di Bantaran Sungai Winongo Kabupaten Bantul, yaitu mengidentifikasi potensi materi ajar pencemaran air dantanah. Berdasarkan analisis data yang diperoleh melalui hasil penelitian eksplorasi tersebut maka dihasilkan produk berupa materi ajar yang dikemas dalam bentuk buku suplemen. Dinamakan buku suplemen materi ajar karena buku ini berisi materi yang ringkas, spesifik, hanya mencakup sebagian kecil sub materi dari sebuah kompetensi dasar. Buku ini sifatnya sebagai pendukung materi pokok, karena materi yang dikembangkan hanya spesifik pada sub pokok bahasan 
mata pelajaran biologi tertentu. Materi dari buku suplemen materi ajar disusun berdasarkan hasil penelitian eksplorasi yang dikemas sedemikian rupa sehingga cocok untuk mendukung materi pokok siswa SMP kelas VII dengan harapan karena materi yang diungkap berdasarkan potensi lokal, maka peserta didik sangat familiar dengan materi di dalam buku tersebut, sehingga hal ini menjadi aspek yang diunggulkan bagi buku suplemen materi ajar dalam hasil penelitian ini.

Buku suplemen materi ajar yang disusun dengan berjudul "Buku Suplemen Materi Ajar Pencemaran Air dan Tanah". Buku suplemen materi ajar tersebut dikembangkan untuk mendukung Kompetensi Inti 3 memahami pengetahuan (faktual, konseptual, dan prosedural) berdasarkan rasa ingin tahunya tentang ilmu pengetahuan, teknologi, seni, budaya terkait fenomena, dan kejadian tampak mata dan 4 mencoba, mengolah, dan menyaji dalam ranah konkret (menggunakan, mengurai, merangkai, memodifikasi, dan membuat) dan ranah abstrak (menulis, membaca, menghitung, menggambar, dan mengarang) sesuai dengan yang dipelajari di sekolah dan sumber lain yang sama dalam sudut pandang/teori serta Kompetensi Dasar 4.3 mengumpulkan data dan melakukan klasifikasi terhadap benda-benda, tumbuhan, dan hewan yang ada di lingkungan sekitar.

Langkah kerja dari pengembangan buku suplemen materi ajar ini adalah sebagai berikut.

I. Melakukan penelitian eksplorasi potensi alam yang ada diwilayah Kabupaten Bantul.

Potensi alam yang diungkap melalui penelitian eksplorasi Bantaran Sungai Winongo Kabupaten Bantul.Di Sungai Winongo terjadi peristiwa pencemawan air.Sesuai hasil penelitian (Vitanovi, 20I4), kasus pencemaran yang terjadi di Sungai Winongo sudah berlangsung cukup lama. Sumber pencemar yang mencemari sungai ini antara lain limbah industri, industri kecil, serta limbah rumah tangga. Akibat yang ditimbulkan dari pencemaran ini antara lain menurunnya kualitas air di Sungai Winongo. Berdasarkan hal tersebut, dilakukan identifikasi jenis-jenis sampah yang terdapat di bantaran Sungai Winongo untuk mendukung materi pencemaran air dan tanah.

2. Melakukan penelahaan hasil kajian penelitian eksplorasi untuk diidentifikasi potensinya sebagai materi ajar biologi di jenjang SMP yang sesuai dengan Kurikulum yang berlaku.

a. Analisis hasil temuan materi ajar biologi

Hasil analisis identifikasi potensi materi pencemaran air dan tanah melalui hasil penelitian eksplorasi pencemaran air di bantaran Sungai Winongo disajikan pada Tabel 3. Berdasarkan hasil tersebut ditemukan beberapa konsep materi yang berpotensimenjadi materi ajar biologi, meliputi: pola interaksi manusia yang mempengaruhi ekosistem, macam-macam pencemaran lingkungan yaitu pencemaran air dan pencemaran tanah, dan pengelolaan limbah. Namun, beberapa konsep materi tidak ditemukan dalam penelitian seperti konsep lingkungan, interaksi ekosistem membentuk pola, dan pemanasan global. Hal ini karena penelitian terfokus pada identifikasi jenis-jenis sampah di bantaran Sungai Winongo yang menjadi penyebab timbulnya pencemaran lingkungan, khususnya pencemaran air dan tanah. Meskipun demikian, pada materi macam-macam pencemaran materi hanya mencakup pencemaran air dan tanah saja, sementara pencemaran udara dan suara tidak dilakukan dalam penelitian.

Berdasarkan hasil dentifikasi jenis-jenis sampah anorganik yang banyak ditemukan di bantaran Sungai Winongo kebanyakan berasal dari limbah rumah tangga. Jenis-jenis sampah yang ditemukan meliputi: plastik, kertas, kain, asbes, sterofom, karet, kaca, logam, bahan kimia, dan busa. Akibat timbunan sampah di bantaran Sungai Winongo tersebut menyebabkan timbulnya pencemaran tanah dan juga pencemaran air (Vitanovi, 2014).

b. Analisis mendalam ketentuan materi ajar yang ditemukan

Berdasarkan temuan-temuan materi berbasis potensi lokal melalui hasil penelitian eksplorasi di bantaran Sungai Winongo sesuai dengan kebutuhan materi ajar biologi SMP. Materi yang ditemukan memenuhi prinsip-prinsip relevansi, adequacy, dan konsistensi. Relevansi artinya materi yang ditemukan ada kesesuaian dengan kebutuhan siswa SMP kelas VII. Ada kesesuaian dengan pencapaian tujuan pembelajaran dan kurikulum yang berlaku. Adequacy artinya materi yang ditemukan cukup mampu menghantarkan pada ketercapaian tujuan pembelajaran dan dapat dijadikan sebagai pengetahuan siswa. Prinsip selanjutnya yaitu konsistensi, artinya bahwa materi yang diperoleh tersajikan secara sistematis dan sesuai dengan urutan materi pada jenjang SMP. Selain itu, sebagai hasil perolehan peserta didik antara lain berupa aspek kognitif (pengetahuan), termasuk diantaranya (fakta dan konsep), aspek afektif (sikap), dan psikomotorik (ketrampilan). Selain itu, hasil perolehan peserta didik yang berupa aspek kognitif, afektif, dan psikomotorik masing-masing dijelaskan pada Tabel 2.

3. Mendesain prototipe buku suplemen materi ajar sebagai wadah dari materi yang ditemukan dari hasil penelitian eksplorasi tersebut.

Pada tahap ini peneliti merancang desain dan sistematika buku suplemen materi ajar, yang meliputi: 
a. Judul buku

Judul buku yang dikembangkan sesuai potensi obyek yang diungkap masing-masing. Judul bukunya antara lain: "Buku Suplemen Materi Ajar materi pencemaran air dan tanah”.

b. Kompetensi inti dan kompetensi dasar

Pada bagian ini berupa kompetensi inti dan kompetensi dasar yang harus dicapai peserta didik.Kompetensi inti yang harus dicapai oleh peserta didik adalah sebagai berikut.

I) Kompetensi Inti 3 memahami pengetahuan (faktual, konseptual, dan prosedural) berdasarkan rasa ingin tahunya tentang ilmu pengetahuan, teknologi, seni, budaya terkait fenomena, dan kejadian tampak mata.

2) Kompetensi Inti 4 mencoba, mengolah, dan menyaji dalam ranah konkret (menggunakan, mengurai, merangkai, memodifikasi, dan membuat) dan ranah abstrak (menulis, membaca, menghitung, menggambar, dan mengarang) sesuai dengan yang dipelajari di sekolah dan sumber lain yang sama dalam sudut pandang/teori.

\section{c. Peta konsep}

Peta konsep merupakan gambaran alur materi yang ada di dalam suplemen materi ajar. Fungsinya untuk mempermudah peserta didik dalam memahami materi.

d. Studi kasus/peristiwa/gambaran umum kekayaan alam suatu obyek.

Fungsi komponen ini sebagai stimulus/gambaran awal yang mengantarkan jalan pikiran siswa menuju pokok pembahasan. Hal ini dapat berupa studi kasus/peristiwa/gambaran umum kekayaan alam suatu obyek. Misalnya pada buku materi pencemaran air dan tanah.

e. Daftar pustaka

Daftar pustaka berisi referensi yang digunakan dalam mengembangkan suplemen materi ajar, sehingga apabila peserta didik ingin mencari informasi lebih lanjut dapat menelusuri acuan yang digunakan dalam mengembangkan suplemen materi ajar tersebut.

4. Mengujikan prototipe buku suplemen materi ajar untuk mendapatkan penilaian kualitas terkait dengan materi, penyajian, dan keterbacaan dari buku suplemen materi ajar yang disusun.

Tahapan ini merupakan tahap uji terbatas oleh guru IPA (Biologi) SMP terhadap produk buku suplemen materi ajar yang telah disusun. Uji terbatas dilakukan dengan menggunakan instrumen penelitian yang berupa angket. Kisi-kisi intrumen penilaian yang digunakan mencakup 3 aspek, yaitu:

a) Aspek materi, terdiri dari 3 komponen yaitu relevansi/ kesesuaian, konsistensi/ keajegan, dan adequacy/kecukupan. Secara garis besar aspek materi memuat pertanyaan berkait dengan kebutuhan materi ajar IPA (biologi) SMP yang diperlukan dan sesuai dengan tuntutan kurikulum.

b) Aspek penyajian, mencakup tampilan dan aturan penulisan. Aspek ini memuat pertanyaan yang berkait dengan penyajian buku suplemen materi ajar.

c) Aspek keterbacaan, berisi pertanyaan mengenai kebahasaan yang digunakan dalam buku suplemen materi ajar.

5. Menganalisis hasil pengujian desain buku suplemen materi ajar

Berdasarkan analisis data yang diperoleh, setelah buku suplemen materi ajar disusun dan mendapat penilaian dari guru IPA (Biologi), secara keseluruhan buku suplemen materi ajar mendapatkan kategori baik. Penilaian tersebut ditinjau dari berbagai aspek diantaranya adalah aspek materi, aspek penyajian, dan aspek keterbacaan. Artinya ketiga suplemen materi ajar yang dikembangkan tersebut layak untuk digunakan dalam pembelajaran, baik di kelas maupun pembelajaran lapangan. Sesuai pendapat Mulyasa (2009), bahwa materi ajar adalah segala bentuk bahan yang digunakan untuk membantu guru/instruktur dalam melaksanakan kegiatan belajar mengajar dikelas. Materi pembelajaran (Instructional materials) berupa pengetahuan, keterampilan, dan sikap yang harus dikuasai peserta didik dalam rangka memenuhi standar kompetensi yang ditetapkan. Materi pembelajaran menempati posisi yang sangat penting dari keseluruhan kurikulum, yang harus dipersiapkan agar pelaksanaan pembelajaran dapat mencapai sasaran. Materi pembelajaran dipilih seoptimal mungkin untuk membantu peserta didik dalam mencapai standar kompetensi dan kompetensi dasar (Depdiknas, 2006).

Berdasarkan hasil penilaian buku suplemen materi ajar materi pencemaran air dan tanaholeh guru IPA (Biologi) pada ketiga aspek, baik aspek materi, penyajian, maupun keterbacaan memperoleh kategori baik. Secara keseluruhan dengan persentase 94,7\%. Pada instrumen penilaian produk rata-rata mendapat nilai satu dengan jawaban "Ya", terdapat satu jawaban "Tidak" pada aspek materi, yaitu pada indikator isi materi memperhatikan ranah/domain pembelajaran yang mencakup ranah kognitif/pengetahuan, ranah afektif/sikap, dan ranah psikomotorik/keterampilan yang akan diperoleh setiap peserta didik. Selanjutnya, dua jawaban "Tidak" pada aspek keterbacaan, yaitu pada indikator bahasa sesuai dengan tingkat perkembangan siswa SMP dan bahasa komunikatif.

Berdasarkan saran yang diberikan oleh guru dalam uji terbatasagar ranah afektif dan psikomotorik terdeteksi dengan jelas, maka sebaiknya dilengkapi dengan kegiatan belajar siswa. Dalam hal ini produk yang dibuat merupakan buku suplemen materi ajar, bukan merupakan modul. Jadi, produk tidak disertai 
latihan kegiatan siswa maupun evaluasi. Selain itu, saran penilai (guru) yaitu untuk menggunakan bahasa yang moderat/lunak sesuai tingkat perkembangan siswa SMP (bahasa santai, ringan dan sederhana). Meskipun demikian dalam catatan angket buku suplemen materi ajar tidak dijelaskan bagian yang harus direvisi.

Secara keseluruhan buku suplemen materi ajar tersebut memperoleh nilai baik. Menurut Sugiyono (2013: I37), tingkat penilaian $X \leq 50 \%$ termasuk kategori kurang/rendah, sedangkan tingkat penilaian $50 \%<\mathrm{X} \leq 100 \%$ termasuk kategori baik/tinggi. Oleh karena buku suplemen materi ajar mendapatkan nilai 94,7\% maka memperoleh kategori baik/tinggi. Artinya, buku suplemen materi ajar yang dikembangkan layak untuk digunakan dalam proses pembelajaran.

Tujuan pembuatan buku suplemen materi ajar adalah untuk melengkapi materi ajar yang sudah ada pada buku-buku ajar biologi SMP, dengan kelebihan terletak pada potensi lokal (local wisdom) yang diangkat sesuai dengan karakteristik kedaerahan. Namun demikin, suplemen materi ajar tetap dikembangkan melalui prinsip-prinsip dasar keilmuan. Menurut Palah (20II), prinsip-prinsip yang dijadikan dasar dalam menentukan materi pelajaran adalah kesesuaian (relevansi), keajegan (konsistensi), dan kecukupan (adequacy).

I. Relevansi artinya kesesuaian. Materi pembelajaran hendaknya relevan dengan pencapaian standar kompetensi dan pencapaian kompetensi dasar. Jika kemampuan yang diharapkan dikuasai peserta didik berupa menghafal fakta, maka materi pembelajaran yang diajarkan harus berupa fakta, bukan konsep atau prinsip ataupun jenis materi yang lain.

2. Konsistensi artinya keajegan. Jika kompetensi dasar yang harus dikuasai peserta didik ada empat macam, maka materi yang harus diajarkan juga harus meliputi empat macam.

3. Adequacy artinya kecukupan. Materi yang diajarkan hendaknya cukup memadai dalam membantu peserta didik menguasai kompetensi dasar yang diajarkan. Materi tidak boleh terlalu sedikit, dan tidak boleh terlalu banyak. Jika terlalu sedikit maka kurang membantu tercapainya standar kompetensi dan kompetensi dasar. Sebaliknya, jika terlalu banyak maka akan mengakibatkan keterlambatan dalam pencapaian target kurikulum (pencapaian keseluruhan SK dan KD) (Depdiknas, 2008: 5).

\section{Simpulan}

Berdasarkan hasil penelitian pengembangan buku suplemen materi ajar biologi SMP melalui hasil penelitian eksplorasi potensi lokal di bantarsan Sungai Winongo Kabupaten Bantul dapat dibuat kesimpulan sebagai berikut.
I.Potensi materi ajar biologi yang dapat ditemukan di bantaran sungai winongo berupa pencemaran tanah dan air, yaitu pada konsep: pengertian pencemaran lingkungan, syarat-syarat suatu zat disebut polutan, macam pencemaran lingkungan (pencemaran udara, pencemaran suara, pencemaran air, pencemaran tanah), pencemaran tanah, jenis-jenis sampah, beserta akibat yang ditimbulkan, pencemaran air, sumbernya pencemaran, jenis-jenis sampah, beserta akibat yang ditimbulkan, dan pengurangan limbah

2. Secara keseluruhan temuan materi berbasis potensi lokal di bantaran Sungai Winongo Kabupaten Bantul sesuai dengan kebutuhan materi ajar biologi SMP serta memenuhi prinsip-prinsip relevansi, adequacy, dan konsistensi.

3. Kualitas prototipe buku suplemen materi ajar yang dikembangkan dengan isi materi ajar berbasis potensi lokal di jenjang SMP memperoleh kategori baik dan layak untuk dijadikan sebagai tambahan materi ajar yang berbasis pada potensi lokal di bantaran sungai Winongo Kabupaten Bantul dan sesuai dengan kurikulum 2013 dengan skor 94,7\% pada Buku Suplemen Materi Ajar Pencemaran tanah dan air.

\section{Daftar Pustaka}

Depdiknas. 2006. Panduan Pengembangan Materi pembelajaran. Jakarta: Departemen Pendidikan Nasional, Direktorat Jenderal Manajemen Pendidikan Dasar dan Menengah, Direktorat pembinaan Sekolah Menengah Atas.

2008. Panduan Pengembangan Materi Pembelajaran. Jakarta: Direktorat Jendral Manajemen Pendidikan Dasar dan Menengah Direktorat Pembinaan Sekolah Menengah Atas.

Mulyasa. 2009. Kurikulum Tingkat Satuan Pendidikan. Bandung: Remaja Rosdakarya.

Palah, Darul. 20I I. "Makalah Materi Pembelajaran". http://darulpalah.blogspot. com/2012/II/makalahmateri-pembelajaran.html. Diakses 26 November 2014.

Suratsih. 2010. Laporan Penelitian Potensi Lokal. Yogyakarta: Jurusan Pendidikan Biologi, FMIPA UNY.

Susilo, M. Joko. 2009. Diktat Pengembangan Bahan Ajar dalam Pembelajaran. Yogyakarta: UAD.

Vitanovi, Penti C.. 20I4. Analisis Potensi Sumber Belajar Ipa (Biologi) SMP Pada Materi Pencemaran Air Di Sungai Winongo sebagai Pendukung Penerapan Kurikulum 2013 di Kabupaten Bantul. Yogyakarta: UAD. 